\title{
135. On the Relation between the Cool Summer in the Northern Japan and the Average Solar Radiation Intensity Measured at the Surface of the Earth.
}

\author{
By Hidetosi Arakawa. \\ (Comm. by T. OKADA, M.I.A., Dec. 13, 1943.)
}

In Figure 1 are shown monthly averages of solar radiation intensity based on measurements made at several different points in the Northern Hemisphere after Herbert H. Kimball ${ }^{1)}$. The monthly means or the monthly maxima of radiation for the different stations have been expressed as a percentage of their respective normals. Then for each month an average of these percentages has been computed, and smoothed by the formula $(a+2 b+c) / 4$, where $b$ is the average percentage for the month in question, and $a$ and $c$ are the average percentages for the preceding and following months, respectively. The smoothed percentages have been plotted in Figure 1, and also a freehand curve that represents the variations in the smoothed monthly values has been drawn. The measurements show marked periods of depression in the solar radiation intensity, as follows :

“(1) In 1884-86, following the eruption of Krakatoa Volcano in 1883. In 1885 the solar radiation was about 20 per cent lower than in 1883 and 1887.

(2) In 1902-03, following the eruption of Pelée, Santa Maria, and Colima in 1902, with a sharp depression in solar radiation intensity at the end of 1902 of 20 per cent.

(3) In 1912-13, following the eruption of Katmai Volcano in June, 1912 , which caused a decrease in solar radiation intensity in the following month of nearly 25 per cent."

The researches of $\mathrm{Abbott}^{2)}$, Humphreys ${ }^{3)}$, and others, indicate that these and earlier volcanic eruptions has been followed by a slight fall in the temperature of the earth as a whole, and especially at continental stations. Prof. T. Okada) calls attention to the fact that these volcanic eruptions that derive a lot of dust into the stratosphere, decrease the surface temperature in the Northern Japan and result in the failure of the rice crop.

The historical failures of the rice crops in the Northern Japan since 1883 to 1930 were as follows :

1) Solar Radiation as a Meteorological Factor, Monthly Weather Review, 59 (1931), 472-479.

2) Do Volcanic Explosions affect Climate? National Geographic Magazine, 24 (1913), 181-198.

3) Physics of the Air, 1920. Chapter on Volcanism, 569-603.

4) 東北地方凶冾の原因，天氣々氣候第 1 卷第 8 號（昭和 9 年）文は氣鱼學 (下卷) 236一 243 頁 (昭和 10 年). 
No. 10] Cool Summer in the Northern Japan and Average Solar Radiation Intensity. 657

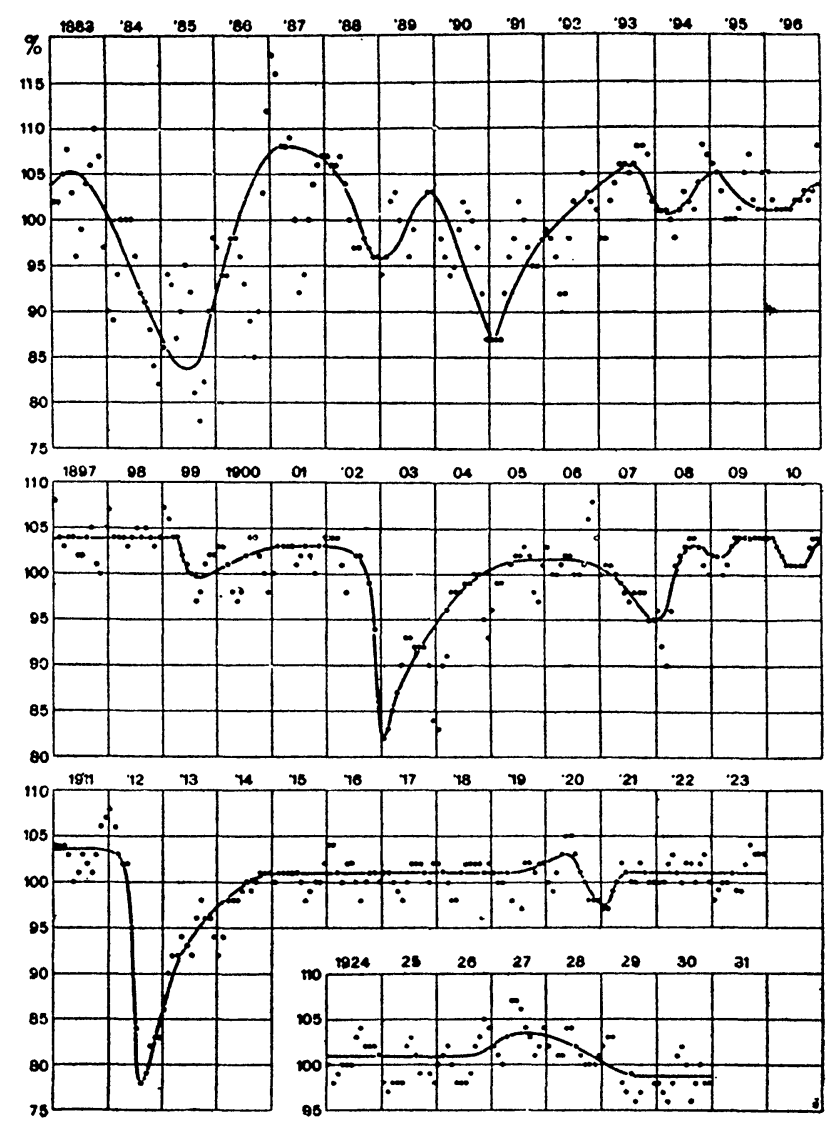

Fig. 1. Monthly averages of solar radiation intensity measured at the surface of the earth, expressed as precentages of the monthly normals (after Herbert H. Kimball).

$$
\begin{array}{ll}
\text { 明治 } 17 \text { 年 } & (1884) \\
\text { 明治 } 35 \text { 年 } & (1902) \\
\text { 明治 } 38 \text { 年 } & (1905) \\
\text { 大正 } 2 \text { 年 } & (1913) .
\end{array}
$$

The mean features of the historical failure of the crops in 1905 are quite different from those in 1884, 1902 and 1913. After Dr. Suda ${ }^{1}$, there are two essential factors of the cause of cool summer, the first factor is the comparatively low temperature of the cold current of Oyasiwo and the sea around the Northern Japan; which result the failures of the rice crops in 1884, 1902 and 1913. The second factor, which results the failure of the crops in 1905, is the frequent outbreaks of the polar continental air mass from Siberia to the districts in question during summer (the critical period).

1) The Cool Summer in the Northern Japan, Anniversary Volume of the Science Reports of the Tôhoku Imperial University, Ser. 1, dedicated to Prof. K. Honda, 1936, 193-207. 
The historical failures of the rice crops in the Northern Japan caused by so-called first factor since 1883 to 1930 , or the failures of the rice crops in 1884, 1902 and 1913 correspond strictly the three greet depressions of the curve in Fig. 1.

On the other hand, since 1912 to 1930 , or for nearly 20 years, there have been no marked volcanic eruptions of an explosive character, such as throw great quantities of dust into the atmosphere. Therefore, the upper atmospheric layers, or the stratosphere, must be unusually clear, and, in consequence, should deplete the incoming solar radiation less than usual. As a result the earth as a whole should experience a slight rise in temperature. And we fortunately have successive good harvest of rice since 1914 to 1930 .

Thus we can conclude that the variations in the measured intensity of solar radiation received at the surface of the earth are quite of importance as a meteorological factor and have significance from the forecasting point of view. 